\title{
Powtoon Animation Video in Introduction to Literature Class: Students' Perception
}

\author{
Sri Yuliani' ${ }^{1}$, Yulianto², Dicki Hartanto3
}

DOI: 10.35445/alishlah.v13i1. 540

\begin{tabular}{l}
\hline Article Info \\
\hline Keywords: \\
Teaching media \\
Powtoon \\
Online learning \\
Introduction to \\
literature \\
Technology
\end{tabular}

Kata kunci:

Teaching media

Powtoon

Online learning

Introduction to

literature

Technology

\section{Abstract}

This research aimed to discover the students' perception of Powtoon animation video in Introduction to literature class. Technology had a significant impact on education. During covid-19, mostly online learning system was applied. Introduction to literature was one of the online class subjects done last semester at odd semester academic year 2020/2021 by using an online system. Sixteen meetings had been done for one semester, and the last project was creating powtoon to tell fiction stories. Thirty-five students involved in this research, and the project of powtoon was created by students as one project accomplishment in this class. The researchers set the qualitative research design by using interview. The interview result revealed that the students were enjoying creating powtoon in this class. They were motivated to use technology in the online class system and found more online media soon.

\begin{abstract}
Abstrak
Tujuan dari penelitian ini adalah untuk mengetahui persepsi mahasiswa tentanf penggunaan Powtoon pada mata kuliah Introduction to Literature Pengguanan teknologi banyak memberikan dampak besar terhadap pendidikan. Selama COVID-19, sebagian besar sistem pembelajaran online telah diterapkan. Introduction to literature merupakan salah satu mata kuliah online yang dilaksanakan pada semester ganjil tahun ajaran 2020/2021 dengan menggunakan sistem online. Enam belas pertemuan telah dilakukan selama satu semester dan proyek terakhir adalah membuat cerita fiksi dalam media powtoon. Tiga puluh lima mahasiswa terlibat dalam penelitian ini dan proyek powtoon dibuat oleh mahasiswa sebagai salah satu pencapaian proyek di kelas ini. Rancangan penelitian kualitatif ditentukan oleh peneliti dengan menggunakan wawancara. Hasil wawancara mengungkapkan bahwa mahasiswa sangat menikmati membuat powtoon di kelas ini dan mereka termotivasi untuk menggunakan teknologi dalam sistem kelas online dan mendapat tantangan untuk menemukan lebih banyak media online dalam waktu dekat.
\end{abstract}

\footnotetext{
${ }^{1}$ Universitas Islam Riau, Pekanbaru, Indonesia sriyuliani@edu.uir.ac.id

2Universitas Islam Riau, Pekanbaru, Indonesia yulianto@edu.uir.ac.id

3Universitas Islam Negeri Suska Riau, Pekanbaru, Indonesia dicki.hartanto@uin-suska.ac.id
} 


\section{INTRODUCTION}

Covid - 19 has enforced lecturers and students in using the online system. The technology used maximally by lecturers and students; however, the complexity of learning occurred that not all lecturers and students were adept at using technology in the online learning process; thus, technology in multimedia is effectively used in teaching and learning (Singh and Singh, 2014), technology build a high-quality teaching and learning environment.

Many kinds of research have been done related to the use of technology in the classroom. Using technology in teaching and learning, using video presentation creates an environment of students felt motivated and felt comfortable (Abou Afach, Kiwan and Semaan, 2018). Besides, the development of innovation is these days inescapable, and it assumes a significant part in schooling. Its effect contains an inventive learning climate that gives educators more authority over instructional decisions, consequently improving learning results. Moreover, Sarkar, Ford and Manzo (2015) stated that adapting technological tools used in education keeps students engaged inside and outside the classroom.

Other researchers, Pavithra et al. (2018), stated that multimedia is the electronic media usage with six components: audio, graphics, text, animation, video, and interaction. This research supports the needs of the teaching-learning process in Introduction to literature class. The integration of technology in teaching and learning activities has been overviewed as a challenging tool that provides students and lecturers to improve the students' productivity and to improve lecturers' creativity in online system education. The online education media uses in language learning class which are familiar during covid-19 are PowToon, Prezi, MS PowerPoint, Slideshare and Adobe Flash (Avsar, Aliabadi, Aliabadi \& Yousefnezhad, 2016).

Tracy Weber (2014) states that Powtoon can be utilized to show any subject; "it very well may be utilized in an English class from students' viewpoint, and surprisingly in a modern expressions class by showing integrating strategies. In addition, Powtoon prepares towards encouraging higherorder thinking abilities like basic reasoning, summing up, and critical thinking, which are essential abilities for effective worldwide education in the 21st century. Many features provided by online media to be used in the online classroom are Powtoon application, which can help the teacher motivate students in learning (Spitalnik, 2013). The integrating all skills of Introduction to literature subject is suitable with the features of Powtoon.

Powtoon is one of the online animation video makers which has been founded at the year 2012 by Ilya Spitalnik. This powtoon provides a feature of creating videos and presentations that every user may create without any training or any tutorial (Spitalnik, 2013). Furthermore, Powtoon commits to integrating technology into education so the learning process runs effectively and efficiently. The complex features inside the powtoon have text, audio, animation, cute images to be selected; moreover, the template is varied like education, business, marketing, medical, so it is appropriate for lecturers, students, researchers and others.

Introduction to literature was a subject provided by English language education in semester 5 . The students should have English literature to get in touch with English cultures to get their background knowledge. Besides that, Introduction to literature taught the students many topics related to literature, and they need engaging multimedia in class, so the class became creative and innovative. This in line with Pourkalhor and Esfandiari (2017) said that studying literature was better using multimedia, so students were free to express some expressions to deliver their thought and feeling. The powtoon media was never used before in Introduction to literature class. Therefore, fiction story became one topic that was chosen to create the student's thinking. Thus, based on the above explanation, the researchers initiated to find out the students' perception to use multimedia, powtoon, in the literature subject as the final project assigned to the students with specific topics was about fiction stories. 


\section{METHODS}

A qualitative research design method was set in doing this research. The research focused on the students' perception of creating powtoon in Introduction to literature class, so they got their own feeling and thought when they processed their powtoon. Their thought and their opinion were described qualitatively. The interview was the instrument used in this research. According to Nassaji (2015), qualitative research is suitable with the English language and teaching because it involves naturalistic data without any intervention and focuses on how something happens.

This research has been done at Universitas Islam Riau at Introduction to literature subject at English language education at odd semester academic year 2020/2021 at semester 5. The researchers chose $5 \mathrm{~A}$ class because one of the researchers was a lecturer of the Introduction to literature subject. The topics to be discussed in this Introduction to literature subject was related to English literature matters. Some of the topics discussed in the subject were fiction, the elements of fiction, reproduction of literature, the definition of poetry and its types, the poetic language, the definition of drama, types of drama and others. As one project in this subject, the students were assigned to create one fiction story in powtoon media with its link website in www.powtoon.com in individual groups and then presented in an online class using google meet.

There were 35 students assigned to create powtoon on fiction topic. One of the topics was fiction. They created fiction stories based on their favourite fiction stories or based on their imaginative stories. The interview was given to the students after the class over, and an online system did it. First, the researchers recorded the students' answer in google meet recording. Then, the researchers did the transcription after finishing her class. Content analysis was used in analyzing the students' transcription. In analyzing the transcripts, the researchers divided five questions given to the students, the first question was "Does powtoon help you in accomplishing your final project?", the second question was "Do you feel comfortable when learning with powtoon?", the third question was "is it easy in operating the powtoon?", the fourth question was "Does powtoon provide interesting animating features?" and the last question was "Do you feel that it is motivated you in creating more powtoon?”.

\section{FINDINGS AND DISCUSSION}

This part discusses the findings obtained from the qualitative data. The interview was used to get the students' realistic opinions and experiences concerning the research interview on their perceptions (Bergman \& Coxon, 2005). There were thirty-five students questioned related to powtoon in Introduction to literature class. The answers were grouped into criteria, the same answers collected into one group and different answers collected in another group. The result of the interview was described in the following:

1. Does powtoon help you in accomplishing your final project?

The majority of students answered that powtoon helped them a lot in finishing their final project, students (AI, AY, AC) said:

"Powtoon helped us a lot in accomplishing our final project, it was very helpful in finishing class project.hm..hm..hm... It took much assistant easily in accomplishing our assignment. We were not worry to make any error in developing our tasks mam. Powtoon made many benefits to us to use it in our class. Powton was really wow...helping us in online class”.

"Powtoon helps us by providing us many features to help us in finishing our project easily. Our skills were challenged in using powtoon. It was such an easy media to be used in finishing our project in Introduction to literature class".

"Yes...powtoon helped us a lot. First of all, I worried if cannot finish the fiction story project on time. I had searched in youtube video about the tutorial in using Powtoon. 
I was able to accomplish my project on time...Alhamdulillah", moreover the display has been built in cartoon characters, animated models and other cartoon objects made this service is very suitable to be used to create teaching media".

Based on the above research finding that powtoon has given a plentiful of assistant was supported by Sarkar et al. (2017) that Powtoon was able to bring helpful concepts for students had given the students' attention and help them in developing some projects assigned by maximizing the tools provided in the powtoon.

2. Do you feel comfortable when learning with powtoon?

Most of the students replied with a positive response about the comfortable of powtoon. Students (NPM, PN, QSD) said that:

"Using powtoon was convenience and comfortable. The application used during the lessons made it easier for us to follow the instruction online individually without any lecturers in guiding us, mam”.

"The powtoon provided us with an opportunity to work independently without any assistance from the lecturers which allowed us more time to elaborate the powtoon comfortably, mam. Self-integrating skill and the tools inside the powtoon were easy to use, so we became more active, self-individual learning, and these tools have made us to be more creative and innovative because we can choose our own favorite actors and images to be used in our powtoon".

"It was comfortable...I loved it. Powtoon was such an online web application system to make an animated cartoon or video presentations comfortably, so I comfortably used Powtoon. My fiction project was successfully finished on time”.

The statement above was lined with the finding of Ashari (2018) revealed that powtoon is one of the software for creating animated features, including handwriting animations, cartoon animations, and more vibrant transition effects and easy timing, so this powtoon application is containing material are combined with animations and transitions to make it more exciting and convenient. In Powtoon, there are various types of animated characters that can support the material presented. Various animated characters also make the material delivered more interesting, moreover, Abou Afach, Kiwan and Semaan (2018), in their research that students felt motivated, felt comfortable in teaching and learning by using technology, especially the using of video presentation.

3. Is it easy in operating the powtoon?

Most of the students replied with "yes". They answered orally that powtoon is easy to be operated.

Students (DN, EN, FA, RSA) said that:

"Yes...it is easy to operate powtoon...Ifelt that almost all features inside this powtoon media could be accessed in one screen, making Powtoon easy used in the process of creating an exposure".

"Wow..that was an easy media to be operated, mam..we just visited the webtoon website Video Maker | Make Videos and Animations Online|Powtoon, then just followed the tutorial from register first, then after register, we continued with log in to the application. Next, we start continuing with choosing character then designing what we were going to design. In this case, we were assigned to create a fiction story which one was our favourite or based on our imagination". 
"Easy mam.... Powtoon was easy application mam...I used this application to other subjects for my presentation mam.... liked this powtoon".

Based on the statement above that most of the students agreed powtoon is easy to be operated was supported by Powtoon (2016) found in his research that powtoon has been created to be accessible in operating with simple instructions and the tutorial also provided to the users.

4. Does powtoon provide interesting animating features?

Almost all students answered that powtoon has many exciting features to be used.

Students (SW, YA, VNI) said that:

"Yes mam..powtoon has many funny animations. I love them, mam...The powtoon can animate our presentation because we can communicate by using animated videos mam....".

"Mam...when I re-watch my video and my friends' video... I laughed mam...hahahaha...because the characters were funny, the sounds were also funny, and animation was also funny..I enjoyed watching more powtoon videos...especially for the class project..'.

"Many interesting images, mam...I chose the cute and funny characters-almost all images in powtoon so interesting. The images were eye catching to be chosen, there were also have text to be written to add the fiction story mam...it was not boring when I designed fiction stories... and one more was sounds were different with other applications...I can add my favorite music too mam".

The above answers were lined with Powtoon (2016), revealed that powtoon could be added with animation to our presentation. Animation video may also add users' various interesting ryhme, repetition, catchy music, and relatable characters into their videos. ese findings also supported by Guo et al. (2014) that the types of video containing different sounds were interesting to students to be engaged in class.

5. Do you feel that it is motivated you in creating more powtoon?

All students agreed with the statement that powtoon had motivated them to create another.

Students (RBS, STA, PN) said that:

"Yes mam...I loved to create other powtoon for another subject mam...liked it..like it...”.

"I would like to mam...I used powtoon mam to finish another class project...it was interesting, mam".

"Mam...powtoon was motivating me a lot...it was easy to use...easy to operate...many interesting and funny features...I can make any imagination for my fiction story by using powtoon...and most important...there was a character in wearing hijab...amazing mam".

The responses from students showed that they were eager to create more powtoon to finish another subject project. These findings supported by Oktaviani, Mandasari, \& Maharani (2020) found that Powtoon, a web application that helped students improve their behavior in learning activity, changed their preference from did not know to be loved. Other research also supported researchers' findings from Pais, Nogués, \& Muñoz (2017). It revealed that powtoon showed positive results not only on the motivational aspect but also on learning new content and developing ICT skill. 
Semaan and Ismail (2018) found that Powtoon video show's advantages, namely, first, permitted students to view and share a subject. Second, a well-prepared powtoon may attract students to focus on the subject. Third, promoted students active in learning. Fourth, Powtoon caused students to accomplish a more noteworthy comprehension of data. Fifth, Powtoon made the class enjoyable due to the mix of visual, auditory and movement, sixth, most basic forms are free or offered at low expenses. Moreover, last, provided essentially viable with numerous working frameworks.

The images below were the final project of powtoon in Introduction to literature class with fiction topics.

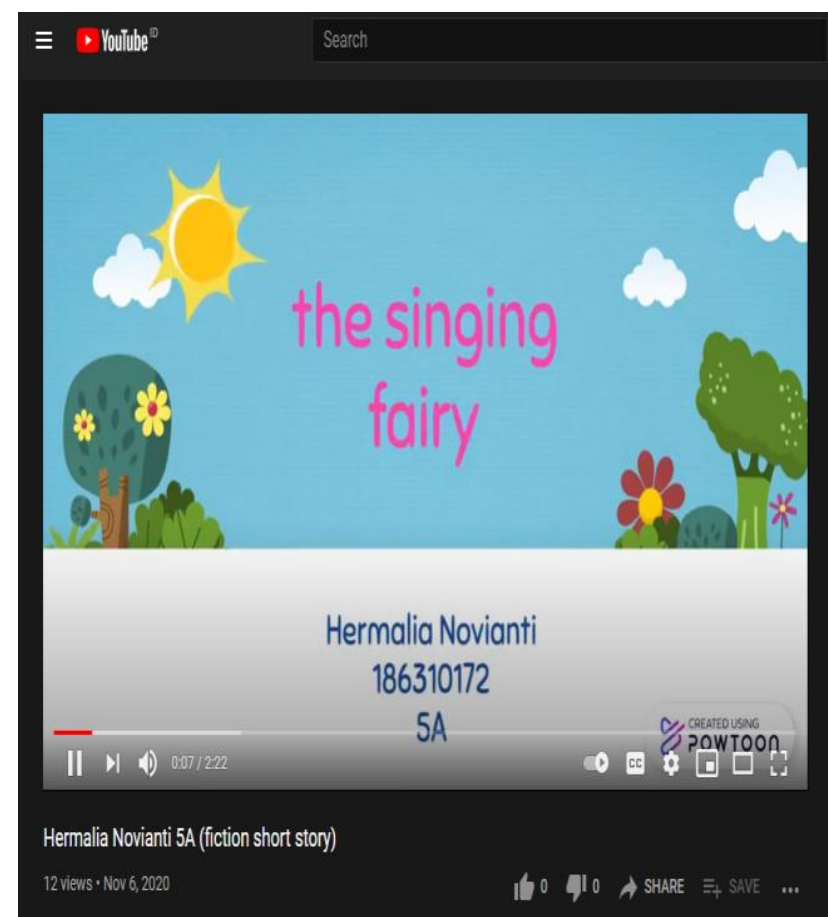

Figure 1. The singing fairy

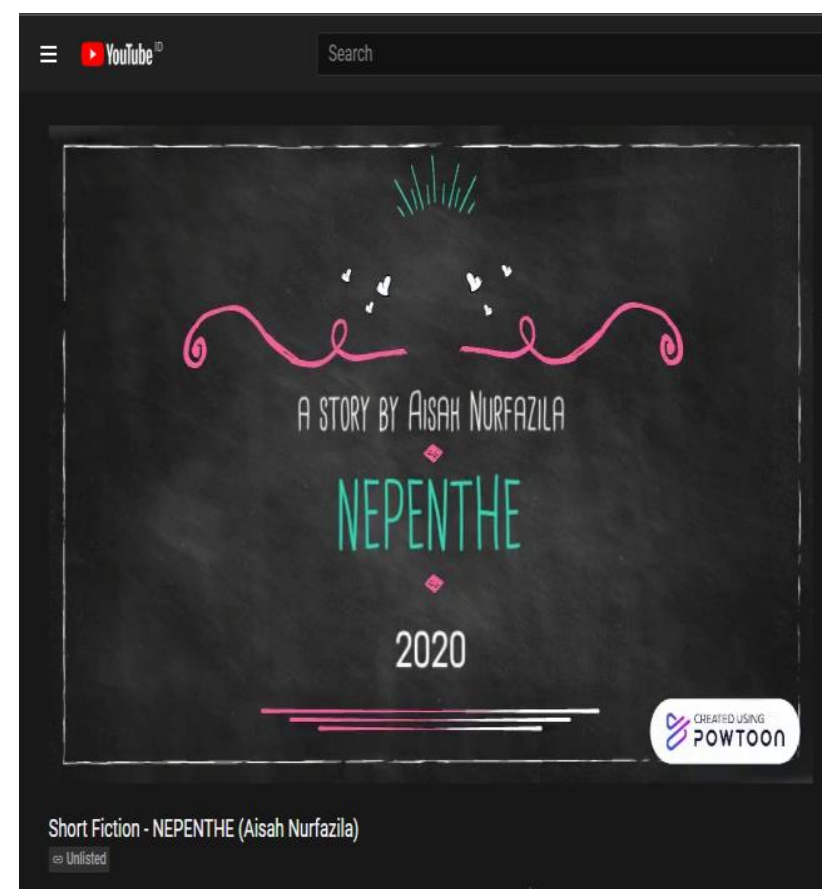

Figure 3. Nepenthe

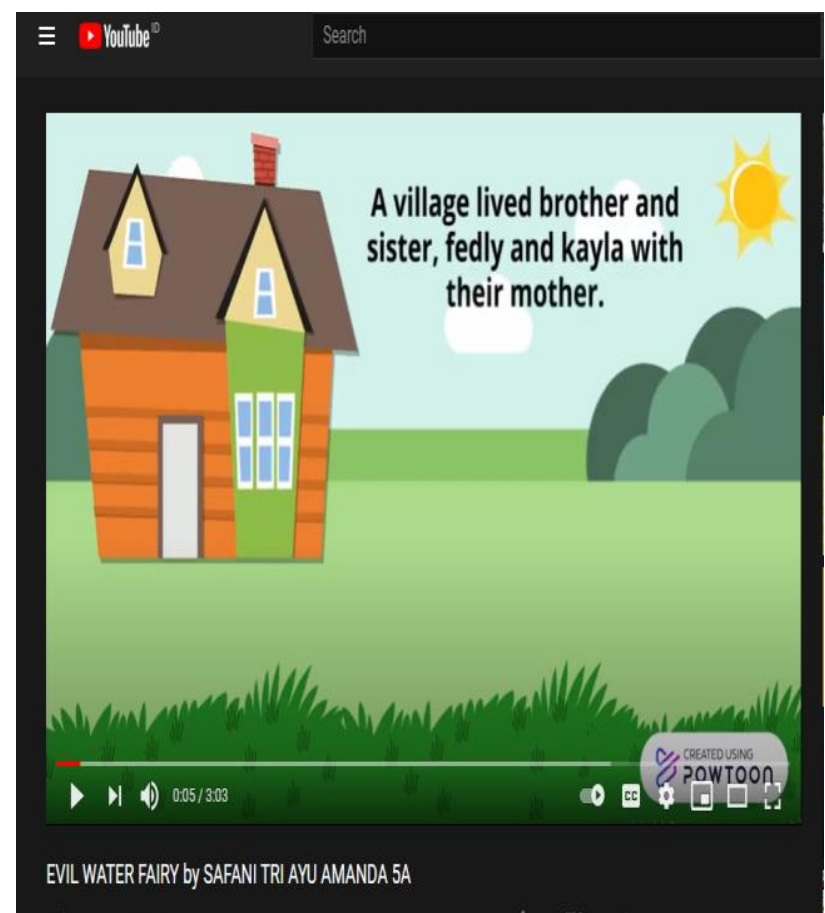

Figure 2. Evil water fairy

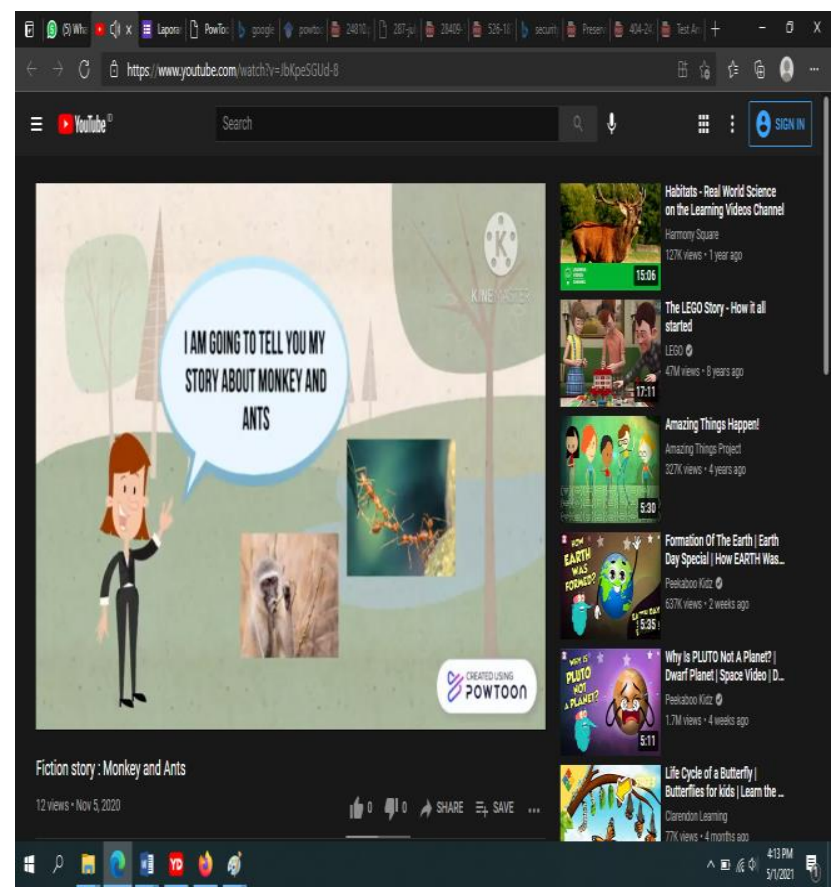

Figure 4. Monkey and ant 


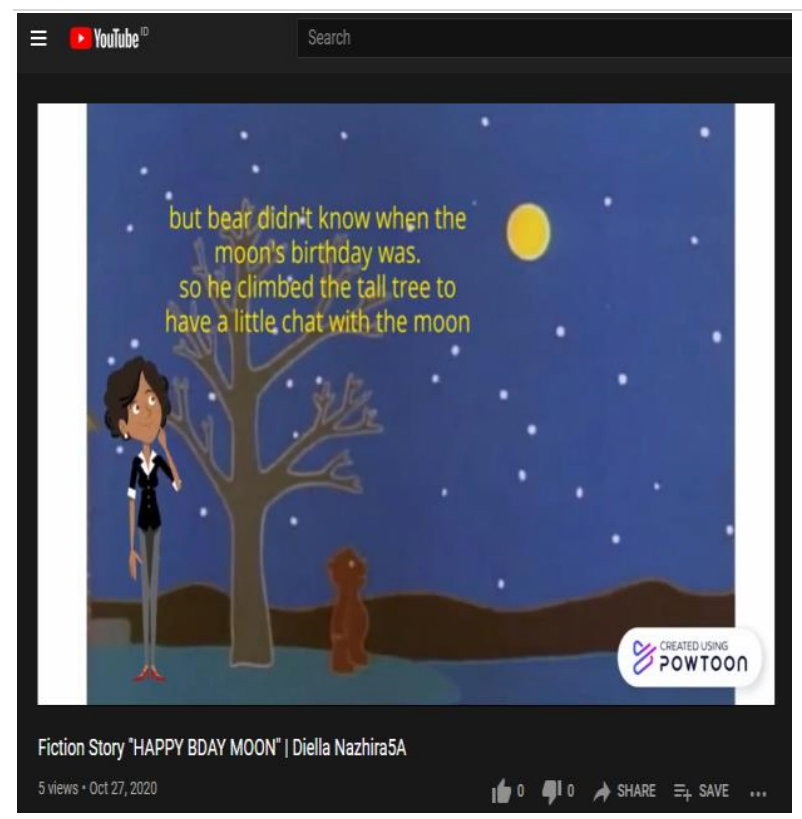

Figure 5. Happy birthday, moon

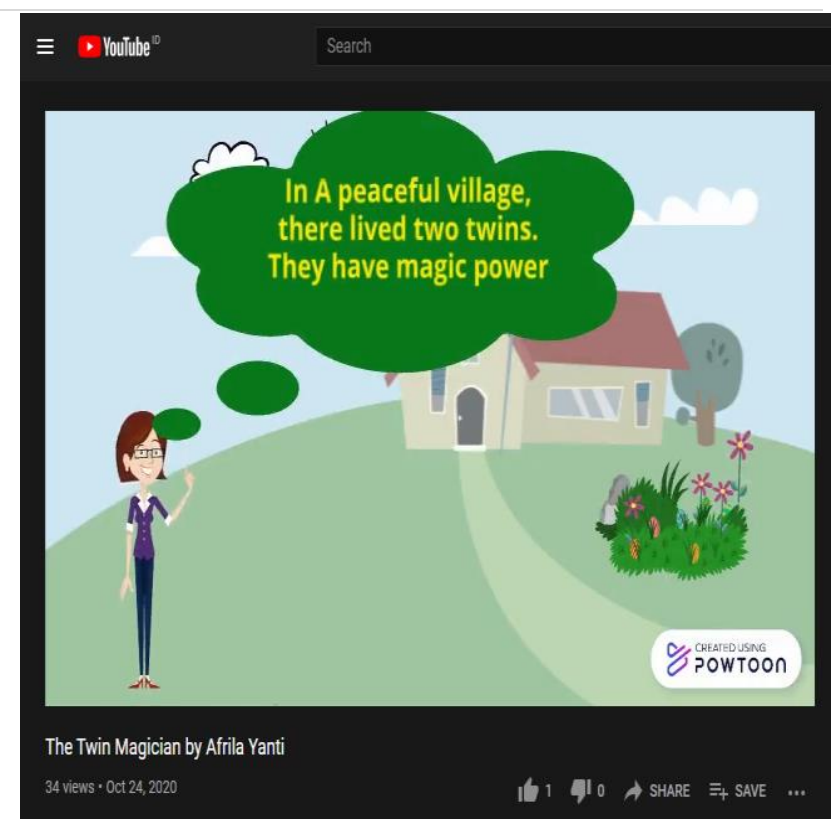

Figure 6. The twin magician

\section{CONCLUSION}

Powtoon is a free-of-charge online animation video application used in an online class or offline class. One of the most exciting and motivating applications to be used by students is that powtoon will become one of the favourite applications. Based on the research findings above, powtoon is a practical and powerful animation video application that supports students finishing Introduction to Literature. Powtoon had helped and assisted $5 \mathrm{~A}$ English language education students in accomplishing their project in term of a fiction story. Powtoon had given such an imagination views when they were searching images for characters provided by powtoon. Moreover, powtoon had supported all students in semester 5 in choosing the animated figures, sound, text, and audio preferences. As a result, the students were eager to use this powtoon application for a more challenging subject.

As a cloud-based movement video maker, Powtoon is an ideal choice of decision. It is protected to utilize because the product should not be downloaded and introduced, and its interface is easy to comprehend for users with no experiences in dealing with innovation. Powtoon has an instinctive interface that guides into making proficient recordings and introductions from a broad scope of formats or without any preparation. Users can make recordings and introductions in less than an hour and incorporate ambient sound from the broad sovereignty free implicit library. In contrast to different applications, Powtoon permits to transfer and alter ambient sound, voiceover, and script.

The limitation of this research was only focused on the students' perception of powtoon in Introduction to literature class. As an implication, hopefully, this research gives an outstanding contribution to other researchers in using powtoon in their class. For other researchers, the effect of powtoon is one alternative idea to be developed for the following research.

\section{REFERENCES}

Abou Afach, S., Kiwan, E. and Semaan, C. (2018). How to enhance awareness on bullying for special need students using EdPuzzle a web 2.0 tool. International Journal of Educational Research Review. Vol. 8, Issue 1. P. 1-7. https://doi.org/10.24331/ijere.372260.

Anggi Silvia Anita And Absharini Kardena. (2021). The Effect of Using Powtoon toward Students' Motivation in Writing. Journal Of English Language Pedagogy. Vol. 6, No. 1, January 2021, Pp. 1-13. Doi: https://doi.org/10.36665/Elp.V6i1.369

Ayub, Siti Ainul Ayzan and Wan Mohamed, Wan Nazihah and Abdul Malek, Nur Ain and Kamarudin, Hanis (2018). Contextual clues Pow Toon for flipped classroom. In: 
Kelantan International Learning and Innovation Exhibition (KILIEX), 15 august 2018, Kota Bharu,Kelantan. https://ir.uitm.edu.my/id/eprint/24810.

Ashari, A.R. (2018). Tutorial Pow Toon. Retrieved April, 2, 2021 from https://www .scribd.com/doc/202979996/Tutorial-Pow Toon

Avsar, B., Aliabadi, D. E., Aliabadi, E. E., \& Yousefnezhad, R. (2016)Academic presenter: A new storytelling presentation software for academic purposes. CoRR, abs/1607.06979. 2016. DOI: $10.33751 /$ jhss.v3i2.1461 Retrieved from https://www.researchgate.net/publication/305542281_Academic_Presenter_a_ New_Storytelling_Presentation_Software_for_Academic_Purpose.

Bergman, Manfred Max \& Coxon, Anthony P.M. (2005). The Quality in Qualitative Methods [54 paragraphs]. Forum Qualitative Sozialforschung / Forum: Qualitative Social Research, 6(2), Art. 34, http://nbn-resolving.de/urn:nbn:de:0114-fqso502344.

C. Semaan and N. Ismail. (2018). The Effect of Using Powtoon on Learning English As a Foreign Language, Int. J. Curr. Res., vol. 10, no. 5, 2018, pp. 69262-69265. https://www.researchgate.net/publication/328702033.

Guo, P. J. Kim, J., \& Rubin, R. (2014). How video affects student engagement: An empirical study of MOOC videos. L@S 2014 March 4-5 2014, Atlanta, Georgia. DOI: $10.1145 / 2556325.2566239$.

Luh Diah Surya Adnyani, G.A.P Suprianti, Ni Putu Era Marsakawati \& Putu Deby Agastya Narotama (2020). Powtoon as the Implementation of Edutainment for Young Learners. Proceedings of the 2nd International Conference on Technology and Educational Science (ICTES 2020). https://doi.org/10.2991/assehr.k.210407.239.

M. H. R. Pais, F. P. Nogués, and B. R. Muñoz. (2017). Incorporating Powtoon as a Learning Activity Into a Course on Technological Innovations as Didactic Resources for Pedagogy Programs, Int. J. Emerg. Technol. Learn., vol. 12, no. 6, pp. 120-131, 2017. DOI: 10.3991/ijet.v12io6.7025.

Nassaji, H. (2015). Qualitative and descriptive research: Data type versus data analysis. Language Teaching Research, 19(2), 129-132. https://doi.org/10.1177/1362168815572747

Oktaviani, L., Mandasari, B., \& Maharani, R. A. (2020). Implementing Powtoon To Improve Students' international Culture Understanding In English Class. Journal of Research on Language Education, 1(1), 19-25. Available online at: https://ejurnal.teknokrat.ac.id/index.php/JoRLE/index

Pavithra, A., Aathilingam, M. \& Prakash, S.M. (2018). Multimedia and Its Applications. International Journal for Research \& Development in Technology, 10(5), 271-276. https://www.academia.edu/38137977/.

Pourkalhor, O. \& Esfandiari, N. (2017). Culture in Language Learning: Background, Issues and Implications. International Journal of English Language \& Translation Studies, 5(1), 23-32. http://www.eltsjournal.org/archive/value5\%20issue1/4-5-1-17.

Powtoon. (2016). How to make an animated explainer video [Blog Post]. 2016. Retrieved from https://www.powtoon.com/videomarketing/animated-explainer-video/

Sarkar, N., Ford, W. and Manzo, C. (2017). Engaging digital natives through social learning. Systematics, cybernetics and informatics, Vol 12, \#2. http://www.iiisci.org/journal/CV\$/sci/pdfs/EBo15YQ17.

Supianti, G.A.P. (2020). Powtoon Animation video: A Learning Media. Vol. 4, No. 2; October 2020. DOI: $10.29408 /$ veles.v4i2.2536

Spitalnik, Ilya. (2013). The Power of Cartoon Marketing. Retreived from: www.PowToon.com

Weber, T. (2014). Tools for Teachers and Students. Techniques: Connecting Education \& Careers, 89(3), 8. DOI: https://doi.org/10.52690/jadila.v1i4.154 